\title{
Determination of Weaning Time of Dombos Lamb Based on Suckling and Eating Behavior and Body Weight Gain
}

\author{
Andrian RN, Nugroho TA, Dartosukarno S, Purnomoadi A \\ Faculty of Animal and Agriculture Sciences, Diponegoro University \\ Kompl. Drh. R. Soejono Koesoemowardojo, Tembalang, Semarang 50275, Central Java, Indonesia \\ agung194@yahoo.com
}

\begin{abstract}
This observation was aimed to determine the suckling and eating duration and body weight gain in Dombos (Domba Wonosobo) lamb aged less than 3 months old to forecast the weaning time. Thirty three male and female lambs with birth type single and twins were used in this study. The equipments for collecting data used webcam that was connected to computer to record the activity of suckling and eating. Data were recorded in $3 \times 24 \mathrm{~h}$ per ewe-lamb, then the tape was analyzed and recorded manually. The results showed that suckling duration has a high correlation with age $(r=-0.821)$, and the lowest duration was found at week 9 , being 5.4 minutes per day. Eating duration and age was highly correlated $(r=0.844)$ with the longest duration was found at week 10, being 178 minutes per day. The body weight gain has a moderate correlation to age $(\mathrm{r}=$ 0.431 ) with the highest body weight gain at week 6 , being $1.9 \mathrm{~kg}$ per week. Based on correlation among age, suckling and eating duration, as well as body weight gain, it is predicted that proposed weaning time of lamb was at week $8^{\text {th }}$. It is concluded from this observation that duration of suckling and eating of lambs were inversely correlated, and lamb was proposed to be weaned at age of 8 weeks.
\end{abstract}

Key Words: Weaningtime, Suckling, Eating, Body Weight Gain

\section{INTRODUCTION}

Dombos (domba Wonosobo) is one of the original breed of Indonesian sheep (Keputusan Menteri Pertanian 2011) which the ewe has a 1.14 littersize and $20.44 \mathrm{~kg}$ of weaned weight. Dombos have a higher body weight than the local sheep, as well as average birth weight of $5.5 \mathrm{~kg}$ for males and $4.5 \mathrm{~kg}$ for females, respectively. The weaning weight of Dombos was $18-20 \mathrm{~kg}$ in males and 16-18 $\mathrm{kg}$ in female at 3-4 months of age (Disnakan Kabupaten Wonosobo 2011).

One of successful standard for animal farming bussiness is the number of weaned lamb and its weaning weight (Van Welie et al. 2016). During the pre-weaning period ewe milk is the only source of nutrients obtained by new born lambs until they are able to consume forage or concentrate. Pre-weaning lambs face the critical period when the ewe reject the lamb to suckle especially at period of early birth until 1 month of age (Teke \& Akdag 2012). At early weeks of birth, usually the ewe allow the lamb to suckle, but increasing of age lead the decreasing duration of suckling due to the rejection from ewe which is lead the lamb search for other nutrient sources, such as solid feed (Jarmuji 2011).

Premature weaning allows the lamb grow less than optimal, but if too long weaning period will prolong the lambing interval and lead inefficiency. Lambs can be weaned when they are no longer dependent on the ewe's milk (Cameron 1998). Based on this reason, the study of determining of weaning time is important, and therefore this study was done to predict the proper weaning time through suckling and eating activity as well as bodyweight gain in the new born lamb aged less than 3 months old. 


\section{MATERIAL AND METHODS}

\section{Lamb and feeding management}

Thirty-three male and female Dombos lambs aged less than 3 months (type of single and twin births) were used. The lamb (together with their ewe) were placed in $1.5 \times 1 \mathrm{~m}$ individual pen. The ewes were fed fresh grass twice a day (06:00 and 16:00) and thereby without the provision of water.

\section{Suckling and eating behavior measurement}

The parameters were observed by duration of suckling, eating and increasing of BW lamb at age less than 3 months. Suckling and eating behaviors were measured by $3 \times 24$ hours and web camera was placed above the pen to record them. The webcam was connected to personal computer that placed outside the pen area in order to let the lamb naturally behave. Suckling duration was measured from the time when the mouth of new born lambs met the teat of ewe till the lamb leave the teat. Eating time was measured from time when the lamb put the mouth in the feeder till the lamb left the feeder. Body weight gain was measured by weighing the lamb weekly using digital hanging scales with $50 \mathrm{~kg}$ capacity $(0.01 \mathrm{~kg}$ of precision).

\section{Data analysis}

The data obtained was correlated to the age by using regression non linier quadratic. The coefficient correlation ( $r$ ) was used to measure the strength of relationship among variables (0 for weak-1 for strong) (Martono et al. 2008).

\section{RESULTS AND DISCUSSION}

Correlation between of suckling and eating duration and age of Dombos lamb is presented in Figure 1. The correlation value of suckling and eating duration to the age was high, being -0.821 and 0.844 . The correlation of suckling and age was negative. It proven that increasing of age will be followed by decreasing of suckling duration, while the eating duration has positive correlation with age and it showed that increasing of age will be accompanied by increasing of the eating duration.

The rejection in eating activity was influenced by several factors, such as the ability of lamb to suckle, nursing rejection by ewe, and the lamb ability to consume solid feeds (forages and concentrates). These suckling and eating activities is principally aimed to fulfill the nutrient requirements of lamb to grow. Thus, suckling and eating activities always occurred inversely because if suckling activity was high so the eating activity was low. Lamb would look for another sources of nutrients if the suckling couldn't met their need of nutrients. Peterson et al. (2006) stated if the lamb got the nutrients from milk less than their need, so it allowed lamb to consume solid feed earlier.

At figure 1, it showed that the lamb suckling duration in week 1 after the birth was longest suckling time and then decreased in everyweeks until reached the lowest at week 9, being 5.4 minutes per day. Meanwhile, the eating pattern of lamb at week 1 of the age after birth was the fewest time and increased in everyweek until it reached the highest at week 10, being 178 minutes per day. The longest of suckling duration indicated that lamb might not depend on the ewe's milk due to insufficience of ewe milk production. The lamb would increase eating duration time to meet their need in nutritions. The intersection of the 
eating time and suckling time at week 3 showed that lamb was already started to try to consume solid feeds. This result closed to the week 4 that reported by Widiyono et al. (2003) as the time of rumen lamb motion could be detected, and continued to increase afterwards. There were three phases of the ewe-lamb relationship in suckling, namely: (1) Week 0-1 was the phase where the lamb could suckle the milk without rejection from their ewe; (2) Week 2-5 was the phase where the lamb suckled on the ewe, but the ewe started to reject the lamb and afterward the frequency rejection getting increased; (3) More than 5 weeks was the phase where the dependence of lamb on milk became less and the lamb began to try other feed (Teke \& Akdag 2011).

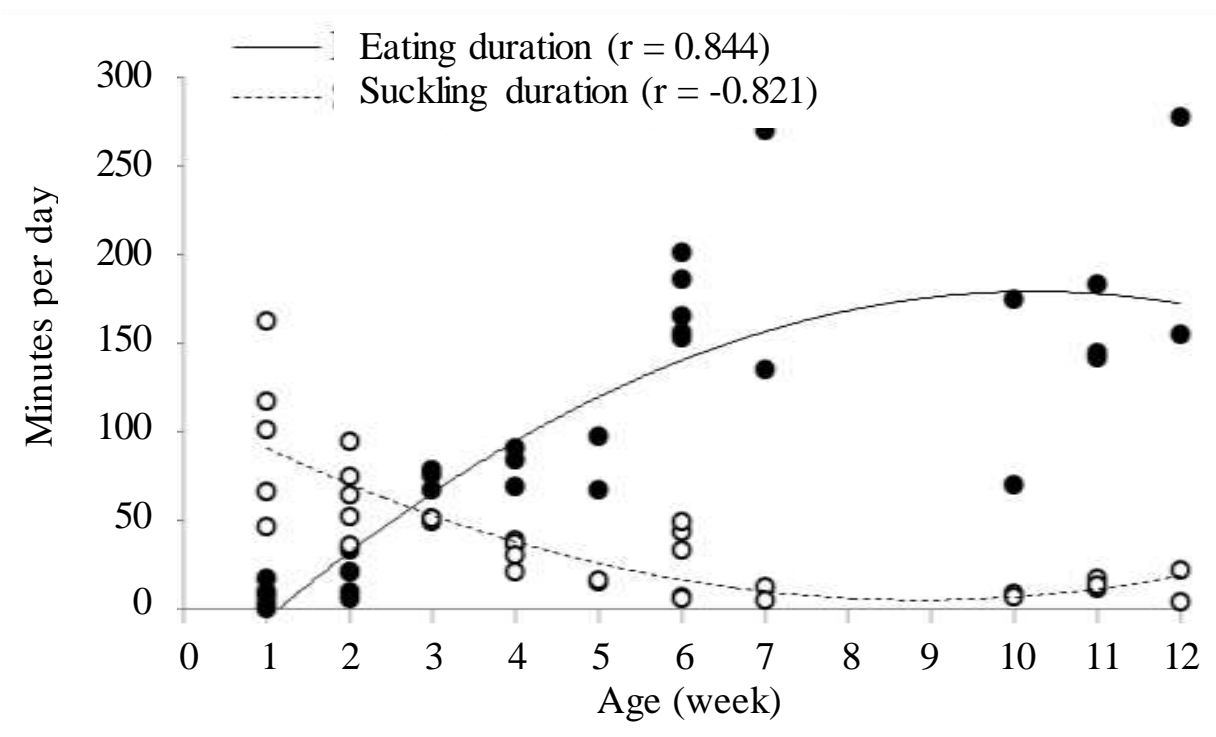

Figure 1. Correlation of age and suckling and eating duration of Dombos lamb

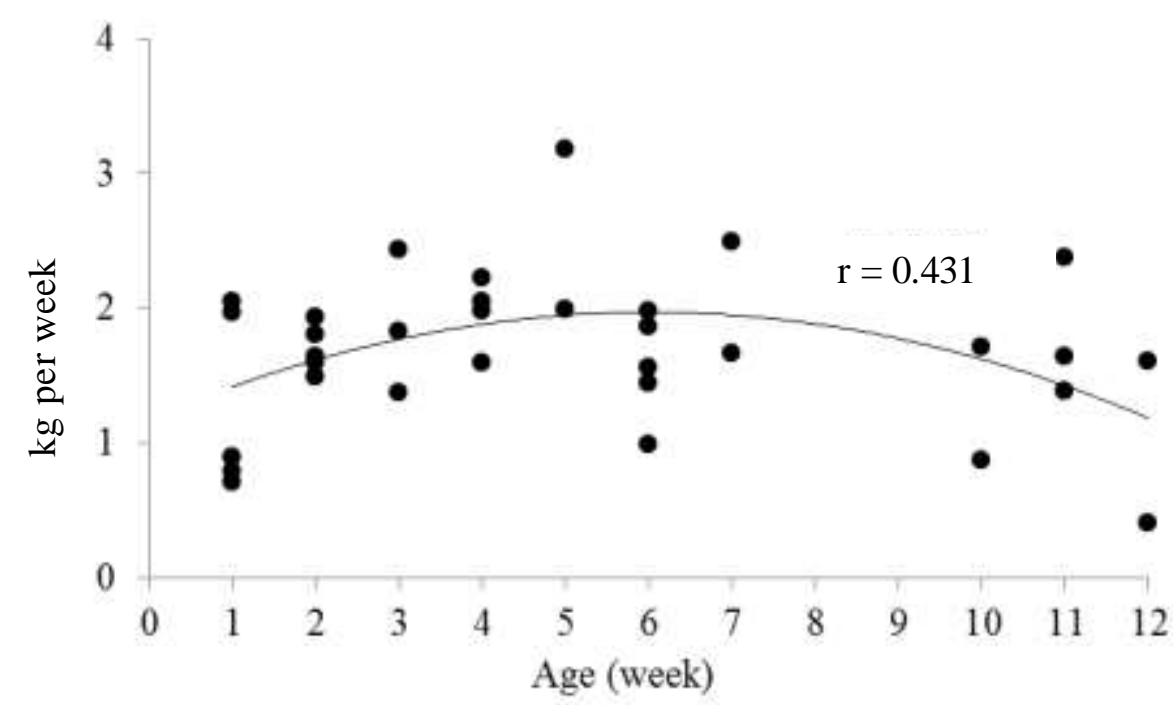

Figure 2. Correlation of age and body weight gain of Dombos lamb

Figure 2 illustrated that the body weight gain of dombos lamb increased when their age increased, and reached a highest body weight gain at week 6 , being $1.9 \mathrm{~kg}$ per week. The correlation value between age and bodyweight gain was middle in strength, being 
0.431. This phenomenon could be considered that at week 6 , the milk production of ewe was unable to meet the nutritions need of lamb. At this age, the rumen condition of lamb wass still in developing, and therefore caused solid feed consumed couldn't be well utilized and resulted in decreasing of body weight. Lamb depend on the ewe's milk until 34 months of age, and slowly started to eat solid feed, and started to show rumination in week 8 (Widiyono et al. 2003). Week 6 to 8 was a period of lamb to adapt the feed from farmer. When the lamb reached week 8 , the body weight gain was highly decreased till week 12. Blank \& Yang (2015) stated that the low nutrition value and milk production of ewe also could reduce the growth rate and weaning weight of lamb. Cameron (1998) stated that the suckling activity has no relationship to the growth of lamb when the milk of ewe was not the only source of nutrients. Based on suckling and eating duration, and body weight gain that discussed above, the weaning time of Dombos lamb could be taken when the lamb reached the age of 8 week old.

\section{CONCLUSION}

The conclusion could be drawn from this study that duration of suckling activity and eating in new born lamb was contrast with age. The proposed weaning time for Dombos lamb could be taken at week 8 of age.

\section{REFERENCES}

Blank D, Yang W. 2015. Suckling behaviour in goitered gazelle: do females invest more in twins or singetons. Zoology. 118:348-356.

Cameron EZ. 1998. Is suckling behaviour a useful predictor of milk intake? a review. Anim Behav Sci. 56:521-532.

Disnakan Kabupaten Wonosobo. 2011. Penimbangan bobot badan dan pencatatan ukuran tubuh domba Wonosobo. Dinas Peternakan dan Perikanan Kabupaten Wonosobo.

Jarmuji. 2011. Nilai korelasi antara ukuran tubuh dan ambing induk domba lokal Jonggol terhadap produksi susu. Agrinak. 1:52-55.

Keputusan Menteri Pertanian. 2011. Penetapan rumpun domba Wonosobo. Jakarta (Indonesia): Kementerian Pertanian.

Martono K, Eryanto R, Noor F. 2008. Matematika dan kecakapan hidup. Bekasi (Indonesia): Ganeca Exact.

Peterson S, Kenyon WPR, Morris ST. 2006. Do ewes with twin and triplet lambs produce different yields of milk and does the grazing behaviour of their lambs differ?. Proc NZ Soc Anim Prod. 66:444-449.

Teke B, Akdag F. 2012. The effects of age of lamb and parity of dam and sex and birth type of lamb on suckling behaviours of Karayaka lambs. Small Rum Res. 103:176-181.

Van Welie LA, Clews SA, Beausoleil NJ, Hickson R, Kongara K, Kenyon PR, Morris ST. 2016. The suckling behaviour and milk intake of one to three week old triplet lambs during natural and competitive suckling situations. Appl Anim Behav Sci. 80:58-64.

Widiyono I, Wuryastuti H, Indarjulianto S, Purnamaningsih H. 2003. Frekuensi nafas, pulpus dan gerak rumen serta suhu tubuh kambing Peranakan Etawa selama 3 bulan pertama kehidupan pasca lahir. J Sains Vet. 19:39-42. 